Загорка О. М., д.військ.н., професор ${ }^{1}$ (ORCID 0000-0003-1131-0904); Можаровський В. М., д.військ.н. ${ }^{2}$; Фролов В. С., к.військ.н., с.н.с. ${ }^{1}$ Загорка I. O. ${ }^{1}$

1 - Центр воєнно-стратегічних досліджень Національного університету оборони України імені Івана Черняховського, Київ;

2 - Центральний науково-дослідний інститут Збройних Сил України, Київ

\title{
Методичний підхід до визначення бойового складу збройних сил воснного і мирного часу
}

Резюме. У статті розглянуто методологічні положення визначення потрібного бойового складу збройних сил для забезпечення воєнної безпеки України.

Ключові слова: бойовий склад; воєнна безпека; мобілізаційні можливості; фінансово-економічні можливості.

Постановка проблеми. Визначення потрібного бойового складу збройних сил (3C) - найважливіша i складна наукова проблема, методологія розв'язання якої належить теорії будівництва ЗС. Складність визначення потрібного бойового складу ЗС зумовлюється необхідністю урахування багатьох факторів воєнно-політичного, оперативно-стратегічного, воєННОекономічного, військово-технічного, нормативно-правового i організаційного характеру.

Від бойового складу насамперед залежить здатність ЗС забезпечити не тільки відбиття агресії, а і можливість утримання противника від розв'язання воєнного конфлікту. Нині в Україні проводяться заходи щодо підвищення боєздатності 3С, зокрема створюються нові військові формування та удосконалюється організаційна структура військових формувань, які знаходяться у складі ЗС. В умовах наявності загроз воєнного характеру і значних ресурсних обмежень для України особливо важливим $\epsilon$ визначення раціонального бойового складу 3 , потрібного для забезпечення воєнної безпеки держави.

Аналіз останніх досліджень i публікацій. $€$ очевидним, що бойовий склад 3С визначає можливості щодо створення угруповань військ (сил) для ведення воєнних (бойових) дій. Під час обгрунтування бойового складу угруповання військ (сил) зазвичай використовується два підходи [1]. У разі використання першого підходу бойовий склад угруповання військ визначається зважаючи на забезпечення максимальної ефективності виконання бойових завдань в умовах обмежень по витратах на його створення та чисельність особового складу. Другий niдxid передбачає визначення бойового складу угруповання військ (сил) для досягнення вимог за ефективністю виконання бойових завдань за мінімальних витрат i мінімальної чисельності особового складу. Під час використання обох підходів застосовується однокритерійний метод оцінювання, що не дає можливості повною мірою визначити збалансований за видами і родами військ склад угруповання військ (сил). Для розв'язання такої задачі пропонується $[2,3]$ застосовувати методи багатомірного аналізу, наприклад, таксономії [4].

У праці [3] запропоновано загальний порядок визначення складу 3С мирного часу та тільки фрагментарно позначено урахування мобілізаційних можливостей країни i можливостей щодо передислокації з'єднань, частин під час створення угруповання військ (сил) для ведення бойових дій на загрозливому напрямку. $\mathrm{y}$ методичних положеннях обгрунтування заходів організаційного будівництва видів 3С, зокрема, Повітряних Сил $[5,6]$, питанням урахування мобілізаційних можливостей також приділяється мало уваги. Отже, можна констатувати, що методологічні положення визначення бойового складу ЗС потребують удосконалення, що і $\epsilon$ метою статті.

Виклад основного матеріалу. 3 огляду на геополітичне положення України можна визначити кілька загрозливих напрямків, на яких можуть бути розв'язані воєнні конфлікти. На кожному напрямку проти ЗС України можуть діяти різні за складом і чисельністю угруповання військ противника. В особливий період ЗС України будуть вимушені розгортати 
угруповання військ (сил) для відбиття агресії. Проте на решті загрозливих напрямках має залишатися визначена кількість військ (сил). Тобто під час визначення бойового складу ЗС воєнного часу необхідно ураховувати як потрібний склад угруповання військ (сил) на одному із загрозливих напрямків для відбиття агресії, так і склад військ (сил), який має залишатися на інших напрямках.
Створення угруповання військ (сил) для відбиття агресії на напрямку розв'язання воєнного конфлікту здійснюватиметься на підставі використання 3'єднань, частин, розташованих на цьому напрямку у мирний час, передислокації з'єднань, частин 3 інших напрямків і проведення заходів мобілізаційного розгортання. Структурна схема методичного підходу до визначення бойового складу 3С наведена на рис. 1 .

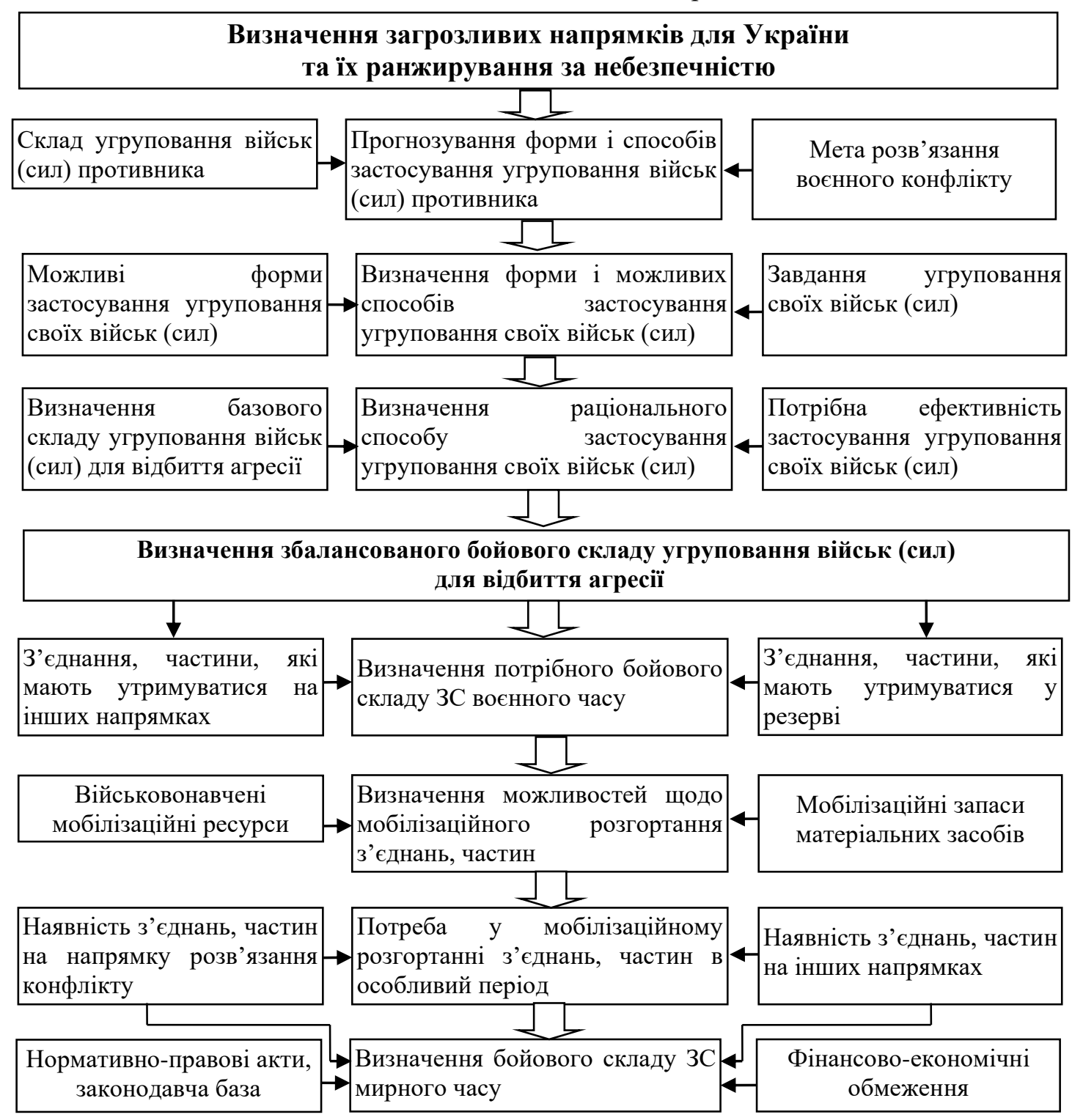

Рис. 1. Структурна схема методичного підходу до визначення бойового складу ЗС

Загрозливі напрямки визначаються на підставі аналізу наявних суперечностей між Україною і суміжними державам, зокрема, у політичній, економічній, територіальній сферах. Для України може бути визначено 3-4 загрозливих напрямки. Ранжирування таких напрямків за небезпекою може бути здійснено 3 використанням експертних методів, зокрема методу аналізу ієрархій (MAI) [7]. Вважається, що розв'язання воєнного конфлікту слід очікувати на небезпечнішому напрямку, на якому потрібно в особливий період створювати угруповання військ (сил) для відбиття агресії.

Створення угруповання військ (сил) має здійснюватися 3 урахуванням прогнозованих форми i способів застосування угруповання військ (сил) противника. Для прогнозування необхідно, насамперед, визначити мету розв'язання воєнного конфлікту i склад угруповання військ (сил) противника. Визначення мети воєнного конфлікту 
здійснюється в умовах дії невизначених чинників, як правило, нестохастичної природи. Через це пропонується [8] для визначення мети воєнного конфлікту використовувати методи теорії нечітких множин, на цім роль імовірнісних законів розподілу чинників віддається функціям належності нечітких множин, які будуються експертним шляхом. Мета воєнного конфлікту визначається за ступенем впливу чинників на альтернативні цілі конфліктів. Форма застосування угруповання військ (сил) противника визначається за допомогою порівняння альтернативних форм [9] 3 використанням MAI.

Для протидії формі i способам застосування угруповання військ (сил) противника також 3 використанням MAI визначається відповідна форма застосування угруповання своїх військ (сил). Відповідно до визначеної форми розробляється сукупність можливих способів застосування угруповання своїх військ (сил). Кожному способу застосування угруповання військ (сил) противника протиставляється спосіб застосування угруповання своїх військ (сил).

Раціональний спосіб застосування угруповання своїх військ (сил) визначається 3 використанням методів теорії ігор. Для цього складається матриця гри (матриця ефективності бойових дій сторін). За показник ефективності приймається співвідношення математичних сподівань величин відносних втрат своїх військ i противника [2], які визначаються за допомогою аналітичних методів або моделюванням операції (бойових дій). Вирішення гри може здійснюватися у "чистих" або “змішаних" стратегіях. Для розв’язання задачі гри доцільно використовувати метод ітерацій [10].

Під час визначення збалансованого бойового складу для відбиття агресії угруповання військ (сил) розглядається, як складна, система організаційно-технічного типу військового призначення i розчленовується на умовні компоненти, які відповідають видам 3C i родам військ. Умовними компонентами можна вважати: сухопутний, авіаційний, протиповітряний, військово-морський. Далі кожна компонента розчленовується на складові, які $\epsilon$ параметрами, що мають оцінюватися у процесі визначення збалансованого бойового складу угруповання військ (сил). До таких параметрів сухопутної компоненти, наприклад, можуть належати: склад механізованих, танкових, аеромобільних військ, ракетних військ i артилерії, військ ППО СВ.

Визначення збалансованого бойового складу угруповання військ (сил) здійснюється за допомогою порівняння варіантів, які відрізняються кількісно-якісними параметрами, що утворюють компоненти угруповання військ (сил), із використанням методів таксономії [24]. Деякі параметри можуть залишатися незмінними. Для формування варіантів бойового складу можуть бути використані евристичні методи або метод планування експерименту [11]. До того ж за початковий склад приймаються кількісні значення параметрів, які були використані під час визначення раціонального способу застосування угруповання військ (сил).

$$
\text { Для визначення потрібного }
$$

збалансованого бойового складу угруповання військ (сил) пропонується використати показники: математичне сподівання (МСП) відносної величини загальних втрат бойового потенціалу військ противника в операції (бою); МСП відносної величини загальних втрат бойового потенціалу своїх військ; МСП внесків компонентів угруповання наших військ (сил) у загальні втрати бойового потенціалу військ противника; МСП частки втрат бойового потенціалу компонентів угруповання наших військ (сил); сумарна вартість створення угруповання військ (сил); вартість засобів ураження компонентів угруповання військ (сил).

Методика визначення збалансованого бойового складу угруповання військ (сил) на теперішній час відпрацьована [2], неодноразово застосовувалась під час проведення науководослідних робіт i не потребує подальшого розгляду. За результатами розв'язання такої задачі визначається найкращий варіант складу угруповання військ (сил) і відповідно кількісні значення параметрів $a_{i}$, які утворюють компоненти збалансованого угруповання військ ( $i=\overline{1, n}, n-$ кількість параметрів). Це дає змогу визначити потрібну кількість бойових 3'єднань, частин видів ЗС і родів військ, які мають містити угруповання військ (сил) на напрямку розв'язання воєнного конфлікту для забезпечення заданої ефективності його застосування в операції (під час ведення бойових дій).

Значення параметрів $a_{i}$ зручно визначати у прийнятих організаційно-штатних структурах підрозділів (батальйони, батареї, ескадрильї). 
Кількість підрозділів $b_{i}, c_{i} i$-го виду, які мають утримуватися на інших напрямках $\mathrm{i}$ у резерві:

$$
b_{i}=k_{1 i} \cdot \alpha_{i} ; c_{i}=k_{2 i} \cdot a_{i}, i=\overline{1, n},
$$

де $k_{1 i}, k_{2 i}-$ коефіцієнти, які визначають співвідношення між підрозділами бойового складу угруповання військ (сил) на напрямку розв'язання воєнного конфлікту i підрозділами, які планується утримувати на інших напрямках і у резерві відповідно.

Коефіціснти $k_{1 i}, k_{2 i} \quad$ визначаються експертами і на підставі досвіду навчань. У разі відсутності необхідності утримування на інших напрямках або у резерві визначеного виду підрозділів коефіцієнти $k_{1 i}, k_{2 i}$ дорівнюють нулю.

Кількість підрозділів $d_{i} i$-го виду, які мають знаходиться у бойовому складі ЗС воєнного часу, визначається за формулою:

$$
d_{i}=\left(1+k_{1 i}+k_{2 i}\right) \cdot a_{i} ; i=\overline{1, n} .
$$

За значеннями параметрів

визначається потрібна кількість бойових 3'єднань, частин видів ЗС і родів військ воєнного часу.

До початку особливого періоду на напрямку розв'язання воєнного конфлікту та інших напрямках може знаходиться визначена кількість з'єднань, частин, склад яких за родами військ (сил) можна позначити через $a_{i}^{*}, b_{i}^{*}$ відповідно. Для створення угруповання військ (сил) на напрямку розв'язання воєнного конфлікту додатково необхідно мати $\Delta a_{i}=a_{i}-a_{i}^{*}$ підрозділів кожного роду військ (сил).

Якщо $b_{i}^{*}>b_{i}$, то частина військ може бути передислокована 3 інших напрямків на напрямок розв'язання воєнного конфлікту, а коли $b_{i}^{*}<b_{i}-$ необхідно інші напрямки підсилити відповідними підрозділами на величину $\Delta b_{i}=b_{i}-b_{i}^{*}$. У цьому разі потреба у мобілізаційному розгортанні за родами військ (сил) може скласти

$$
\Delta d_{i}=\Delta a_{i}+\Delta b_{i}+c_{i}
$$

Можливості по додатковому мобілізаційному розгортанню з'єднань, частин визначаються з урахуванням наявності мобілізаційних запасів матеріальних засобів, зокрема, OBТ, можливостей по підготовці і накопиченню

військовонавчених

мобілізаційних ресурсів [1].

До того ж необхідно ураховувати значні обмеження щодо мобілізаційного розгортання з'єднань, частин Повітряних Сил. Це, насамперед, обумовлюється: специфікою ОВТ, які потребують особливих умов зберігання; їх складністю, що знижує можливості щодо підготовки фахівців, збільшуе терміни розгортання. Отже бойовий склад ПС під час переводу їх на воєнне положення не має значно змінюватися.

Для додаткового розгортання з'єднань, частин Сухопутних військ важливою $\epsilon$ організація підготовки резерву. Заслуговує на увагу досвід підготовки резерву, який реалізовано у ЗС Білорусії [12]. Він передбачає призов на службу в резерві за міліційним принципом. Резервісти зобов'язані опановувати військово-облікові спеціальності без відриву від навчання чи роботи протягом трьох років, відвідуючи заняття при військових частинах. Резервісти разом із силами мобілізаційного резерву в особливий період мають скласти основу сил оборони країни.

У ЗС України також реалізується Концепція служби у військовому резерві [13]. На кінець 2012 р. співвідношення чисельності резервістів до загальної чисельності ЗС становило 1,5\%, що значно менше порівняно 3 арміями інших держав (Польща - $10 \%$, Велика Британія - $14 \%$, Франція - $28 \%$ ) [14].

Можливості щодо мобілізаційного розгортання з'єднань, частин в особливий період $\left(d_{i}^{*}\right)$ доцільно також визначати за родами військ (сил). Це дає змогу більш спрямовано планувати підготовку спеціалістів. Коли $d_{i}^{*}<\Delta d_{i}$, то потребується у мирний час утримувати більшу кількість військ (сил) на величину

$$
\Delta d_{i}^{*}=\Delta d_{i}-\Delta d_{i}^{*} .
$$

Тоді бойовий склад родів військ (сил) мирного часу

$$
r_{i}=a_{i}^{*}+b_{i}^{*}+\Delta d_{i}^{*} .
$$

За оцінками параметра $r_{i}$ визначається бойовий склад ЗС (з'єднання, частини) мирного часу.

Далі відповідно до методичного підходу, що розглядається, необхідно здійснити перевірку фінансово-економічних можливостей щодо утримання визначеної кількості з'єднань, частин у мирний час. 
Якщо фінансово-економічних можливостей держави не вистачає, необхідно скоригувати завдання 3С або вжити заходів щодо збільшення мобілізаційних запасів матеріальних засобів і удосконалення підготовки військовонавчених мобілізаційних ресурсів.

$$
\text { у разі, коли } d_{3}^{*}>\Delta d_{3} \text { можливе }
$$

скорочення кількості підрозділів родів військ (сил) мирного часу.

Особливість розглянутого методичного підходу полягає в урахуванні під час визначення бойового складу 3С воєнного i мирного часу потрібного і збалансованого за родами військ (сил) бойового складу угруповання військ (сил) для відбиття агресії та можливостей щодо додаткового мобілізаційного розгортання з'єднань, частин в особливий період.

Висновок. Запропонований методичний підхід дає змогу визначити бойовий склад ЗС воєнного і мирного часу. Наведені положення грунтуються на декомпозиції потрібного для відбиття агресії бойового складу угруповання військ (сил) на умовні компоненти i використанні методів таксономії для забезпечення їх збалансованості та на урахуванні можливостей ЗС щодо мобілізаційного розгортання з'єднань, частин.

Надалі доцільно докладніше розглянути методичні положення оцінювання мобілізаційних можливостей $3 \mathrm{C}$ в особливий період.

\section{СПИСОК ВИКОРИСТАНОЇ ЛІТЕРАТУРИ}

1. Основы теории и методологии планирования строительства Вооруженных Сил Российской Федерации: Военно - теоретический труд / Под общ. ред. А. В. Квашнина. - М.: Воентехиздат, 2002. - 232 с.

2. Можаровський В. М., Загорка О. М. Основні положення методики визначення варіанта (способу) бойових дій та складу угруповання військ (сил) для відбиття агресії / В. М. Можаровський, О. М. Загорка // Наука i оборона. - 2011. - №1. - С. 3 - 6.

3. Тимошенко Р. I., З Загорка О. М. Загальні методологічні положення воєнно - економічного обгрунтування складу Збройних Сил України на сучасному етапі ї реформування / P. І. Тимошенко, О. М. Загорка // Наука і оборона. - 2014. - № 1. - С. 43 - 48.

4. Плюта В. Сравнительный многомерный анализ в экономических исследованиях: методы таксономии и факторного анализа / В. Плюта; пер. с пол. В. В. Иванова. - М.: Статистика, 1980. -151 c.
5. Руснак I. C., Загорка О. М. Розвиток методологічних положень обгрунтування заходів організаційного будівництва (реформування) Повітряних Сил Збройних Сил України / I. С. Руснак, О. М. Загорка // Наука і оборона. 2014. - № 3. - C. 17 - 22 .

6. Байдак Ю. А., Загорка О. М., Гамора В. В., Коваль В. В. Організаційне будівництво Повітряних Сил Збройних Сил України: методичні аспекти / Ю. А. Байдак, О. М. Загорка, В. В. Гамора, В. В Коваль // Наука і оборона. 2014. - № 1. - С. 43 - 48.

7. Саати Т., Кернс К. Аналитическое планирование: Организация систем / Т. Саати, К. Кернс; пер. с англ. Р. Г. Вачнадзе. - М.: Радио и связь, 1991. - 224 с.

8. Загорка О. М., Марко І. Ю. Використання експертно-аналітичних методів для прогнозування мети воєнного конфлікту / О. М. Загорка, I. Ю. Марко // Сучасні інформаційні технології у сфері безпеки і оборони. - 2013. - № 2 (17). С. $76-80$.

9. Кириченко I. О., Загорка О. М. Визначення форм i способів застосування військ (сил) у локальних війнах i збройних конфліктах: методологічний аспект / І. О. Кириченко, О. М. Загорка // "Честь і закон”. - 2005. - № 4. - С. 17 - 21 .

10. Вентцель Е С. Исследование операций / Е. С. Вентцель. - М.: Советское радио, 1972. $552 \mathrm{c}$.

11. Барабащук В. И., Креденцер Б. П., Мирошниченко В. И. Планирование эксперимента в технике / В. И. Барабащук, Б. П. Креденцер, В. И. Мирошниченко; под ред. Б. П. Креденцера. К.: Техника, 1984. - 200 с.

12. Медвідь М. М. Механізм регулювання зайнятості у військових формуваннях та правоохоронних органах спеціального призначення / М. М. Медвідь - Х.: Национальна акад. НГУ, 2014. - 346 с.

13. Про затвердження Концепції служби у військовому резерві Збройних Сил України: наказ міністра оборони України від 16.12.2011 р. № 774.

14. Біла книга 2012. Збройні Сили України. - К.: Міноборони України, 2013. - 74 с. 
Загорка А. Н., д.воен.н., профессор ${ }^{1}$;

Можаровский В. Н., Д.воен.н. ${ }^{2}$;

Фролов В. С., к.воен.н., с.н.с. ${ }^{1}$;

Загорка И. А. ${ }^{1}$

1 - Центр военно-стратегических исследований Национального университета обороны Украины имени Ивана Черняховского, Киев;

2 - Центральный научно-исследовательский институт Вооружённых Сил Украины, Киев

Методический подход к определению боевого состава вооруженных сил в мирное и военное время

Резюме. В статье рассмотрены методологические положения определения необходимого боевого состава вооруженных сил для обеспечения военной безопасности Украины.

Ключевые слова: боевой состав; военная безопасность; мобилизационные возможности; финансово-экономические возможности.

A. Zagorka, DsM, professor ${ }^{1}$;

V. Mozharovsky, DsM ${ }^{2}$;

V. Frolov, PhD (Military), senior researcher ${ }^{1}$;

I. Zagorka ${ }^{1}$

1 - Center for Military and Strategic Studies of the National Defence University of Ukraine named after Ivan Cherniakhovskyi, Kyiv

2 - Central Research Institute of the Armed Forces of Ukraine, Kyiv

Methodical approach to determining the combat composition of the Armed Forces in peacetime and wartime

Resume. The article discusses the methodological provisions for determining the necessary combat strength of the Armed Forces to ensure the military security of Ukraine. capabilities.

Keywords: combat strength; military security; mobilization capabilities; financial and economic 